telephone is a farspeaker, a vacuum cleaner a dustsucker and a bra a bosomholder). Nor is he distressed by mixed derivations, which he holds to be inescapable, but he inveighs magisterially against the reckless and classically illiterate coinages that are tossed in growing profusion into the medical (and scientific) literature, and left there to fester.

The Language of Medicine contains besides much else, an entertaining section on the names of commercial products (though this is an area that could be quarried for a learned volume all on its own: according to E.S. Turner's history of advertising, there have been, to take only one instance, not less than sixteen tradenames for phenolphthalein alone). There is a richly diverting chapter on the argot of doctors, patients, nurses and typists, and another, with the title "Diseases of the Tongue", that treats of the abuse of language and contains some examples of modern medicalese so monstrous they have a certain majesty. If it pleases you to know that hysteria means womb-trouble, that influenza comes by way of stellar influence, that testis, meaning witness, recalls the early custom of placing the hand over the testicles when taking an oath, and that Botulinus derives from botulus, a sausage, then you should seek the means to possess this beguiling book, even to the extent of laying out hard cash.

A Treasury for Word Lovers is not of the same calibre. It is a collection of short essays, one or two to a page, mostly on vogue words and others frequently misused. There is sound instruction for the less literate reader, who might however find what he needs more readily in something on the lines of Room's Dictionary of Confusibles. Mr Freeman is no Thurber or Mencken, but he writes pleasantly, and a random trawl brought up some agreeable items. Tested on some common modern solecisms, the book scored well enough. It is excellent on that and which, for instance, and properly excoriates the illiterate usage of hopefully, with several examples but no indication of how this curious aberration has infiltrated the language. (My own surmise is that it originated in German-American emigranto, or Hyman-Kaplanese, in which hoffentlich, rather than hoffnungsvoll, was rendered as "hopefully".) $\mathrm{Mr}$ Freeman denounces the horrors of modern media prose wherever he encounters it. $\mathrm{He}$ gives no examples as arresting as the words of a New York broadcaster not long ago, who witnessed an accident, in which a helicopter plunged into the East River. "We have," he said, "a zero-survivability situation". We should be grateful to the likes of Dr Dirckx and Mr Freeman for standing between the English language and a like predicament.

Walter Gratzer is in the Medical Research Council Cell Biophysics Unit, King's College, University of London.

\section{The long shadow of Lysenko}

\section{Edward N. Trifonov}

Principles of Modern Genetics, 2nd Edn. By S.M. Gershenson.

Naukova Dumka, Kiev: 1983. Pp.560.

Price not known.

THE gradual transition from classical to molecular genetics during the 1940 s and 1950s was a time of painful rebirth for Russian geneticists. Most of them, Mendelians, had been repressed, and in many cases virtually condemned to death in labour camps. Sergei Mikhailovich Gershenson was one of the few who somehow reappeared alive.

Gershenson's early studies on the sexchromosomes of fruit-flies (1928-1935) are still occasionally discussed in books on classical genetics, but his interests today are mostly in the field of molecular biology (of insect viruses, specifically). Probably because of this, his textbook is comprehensive and neatly balanced between classical and molecular genetics.

It soon becomes clear that the book, which is in Russian, is written by an excellent lecturer - one can almost feel the passion of a committed teacher as the author carefully covers a complexity of factual information, leading to exact concluding formulations at the end of each chapter. The first half of the book displays the key ideas of genetics, both in their original and their modern context. Mendelian laws are elegantly introduced via green and yellow Chlamydomonas, thus postponing the traditional statistics of Mendel's peas. Chromosomal theory is then unravelled, bringing the reader logically rather than chronologically to the revelations of molecular biology. All basic

\section{Sea views}

\section{P.M. Holligan}

Oceanography: The Present and Future.

Edited by Peter G. Brewer.

Springer-Verlag: 1983. Pp.392. DM 110, $\$ 45.50$.

A symposIUM "Will We Use The Oceans Wisely - The Next Fifty Years in Oceanography", held at Woods Hole, Massachusetts in 1980 to mark the fiftieth anniversary of the founding of the Oceanographic Institution, forms the basis of this book. It consists of twenty-two short articles organized into sections on small-, regional- and global-scale oceanography, as well as the human scale of resources and communications. Authors from a diverse range of disciplines provide authoritative summaries of present work, speculation terminology, conveniently picked out in bold type, is introduced sequentially and is well explained; Gershenson has evidently taken great pains over the continuity of his account. Nor is the text ever dull, punctuated as it is by relevant anecdotes one example is the story of a simple-minded gardener who selected seeds of pink flowers to plant all over town; sure enough, the resulting blooms showed segregation to red and white.

The rest of the text is an introduction to more specialized branches of genetics and molecular biology, and includes quite recent developments in genetic engineering, immunogenetics, transposons, splicing and oncogenes.

Somewhat unusual for this kind of book is the inclusion of chapters on nonheritable modifications, ontogenesis, evolution and practical selection. It is difficult to escape the feeling that these sections are the long delayed echoes of times when Russian genetics was under criminal investigation. For example, Lysenko appears in the introductory chapter as a scholar whose theories just happened to be wrong. One can only guess at what actually happened from a few passages such as "Genetic studies in the USSR revived after a period of decline ..." or "Genetics is taught in all Universities . . " and "The All-Union N. Vavilov Society of Geneticists and Selectionists ... broadly propagates achievements of genetics"' (Vavilov died in prison in 1943). It is hard to say whether the author chose not to discredit Lysenko, or was prevented from doing so by censorship; probably both, in a diabolically concerted way. Apart from such aberrations, however, this is a textbook of high quality, one which bears comparison with its Western counterparts.

Edward N. Trifonov is at the Weizmann Institute of Science, Rehovot, Israel.

about the future and, in some cases, anecdotal accounts of the past which make the whole book most enjoyable. It succeds well in conveying the interdisciplinary nature of oceanography and the problems of investigating processes over very wide temporal and spatial scales.

The editor regrets the omission of the geological and geophysical contributions from the book. It also seems a pity that some general account of biological production could not have been included, especially as recent progress in understanding the interaction between biological activity and the geochemical cycles is already leading to new lines of research.

Three consistent themes emerge in the book. First, rapid developments in instrumentation and techniques of data analysis have led to an immediate need for innovative scientists to investigate oceanic processes by new methods such as direct velocity measurements and remote sensing. 